\title{
ARTICLES
}

Klio. Czasopismo poświęcone dziejom Polski i powszechnym

PL ISSN 1643-8191, t. 55 (S)/2020, s. 231-251

(c) (1) $\Theta$

http://dx.doi.org/10.12775/KLIO.2020.042

MagdALENA NiedZIELSKA*

\section{Iron-nail war landmarks in West and East Prussia during the Great War}

Summary: The subject of this article is the emergence of a today long-forgotten ritual that spread in wartime Germany and Austria in 1915 and 1916: the creating iron-nail "war landmarks". War landmarks had essentially three dimensions: these were propaganda spectacles that increasingly took on a commemorative role and were meant to express the gratitude of the home front to the soldiers and their families. The nailing ritual was meant to forge a new Volksgemeinschaft, performing the nation at war. This article presents original research on the history of the iron-nail war landmarks in West and East Prussia in First World War.

Keywords: West and East Prussia, iron-nail war landmarks, First World War

The paper was originally published as „Pomniki żelazne” I wojny światowej w Prusach Zachodnich i Wschodnich, "Klio" 2016, vol. 36 (1), pp. 69-90, DOI: 10.12775/ KLIO.2016.004.

Institute of History and Archival Studies, Nicolaus Copernicus University, W. Bojarskiego 1 St., 87-100 Toruń; nie@umk.pl; ORCID: 0000-0003-1846-931X. 
Cor the German Reich, the World War started on the 1 August 1914 with the declaration of war against Russia. What, at first, seemed just a brief conflict to be finished with a brilliant victory, in the subsequent months turned into a lingering war requiring dedication and self-denial from the German society. The war efforts, constant changes of the situation on the front lines, sacrifices of human lives and soldiers' health all posed a new challenge also for those who were not directly participating in the fights.

Other than the obvious and spontaneous militarisation arising from the war situation, the public was also influenced by propaganda activities which were aimed at the maximal mobilisation of all social classes to take part in the war effort. For this purpose, the Prussian, German and even Teutonic symbolism of war, mythology, and traditions hailing the war glory of the past were addressed.

One of such traditions, rediscovered or maybe only redefined, was a custom of founding in German cities war landmarks and monuments of patriotism for the Reich and the ruling dynasty in the form of various spatial forms, the surfaces of which were covered with metal nails; each of them symbolised an individually contributed monetary offering for the war purposes (Ger. Kriegshilfe). Depending on the amount, the donator gained a possibility to choose a more exposed location, size, or a more precious metal of which the nail was made. To describe this practice, a term "Kriegsnagelung" is used in German, which has no equivalent in English.

This idea was born at the beginning of 1915 in Vienna. On 15 February 1915 at a meeting of the committee managing the funds for widows and orphans (Zentralkomitee des Witwen- und Waisenhilfsfonds), at which the Austrian successor to the throne -duke Charles Stephen was present, the navy captain earl Theodor Harting proposed to use the symbol of Vienna, the so called Stock-im-Eisen, to strengthen the patriotic spirit. The legend of a spruce trunk with nails dates back to the beginning of the sixteenth century, as its first record appeared in 1533. At the beginning of the twentieth century, it was situated in one of the Vienna squares, granting it the name Stock-im-Eisen-Platz 3. The provenance of the custom has not been sufficiently explained to this day, although it is certain that it was related to 
some already existing rituals. ${ }^{1}$ Independently of the Vienna initiative, similar ones emerged in 1914 in Germany, among others: in September that year in Duisburg, in December in Ruhla and Villingen. They were initiated by groups of friends who had fought together on the front lines aiming to support their impoverished families. ${ }^{2}$

The statue of the armoured knight (Wehrmann in Eisen), which today is situated in an arcade next to the Vienna town hall, was unveiled on 6 March 1915 in Schwarzenberg Square. It gave rise to a movement which in the subsequent months of 1915 encompassed not only the Habsburg Monarchy, but also the whole German Reich. As early as on 23 April 1915, the next memorial - the Iron Cross -was installed in Darmstadt, and on 12 May 1915, another in Heilbronn (a figure of a knight). ${ }^{3}$ A true wave was brought by the first anniversary of the battle of Tannenberg in Eastern Prussia (26-30 August 1915), with its high points on Sunday, 29 August; ${ }^{4}$ then, slightly later, in October, accompanying the commemoration of the battle of Leipzig in 1813 (16-19 October); and on Emperor's Wilhelm II birthday, 27 January 1916.

The first iron-nail war landmarks were usually statues: of Roland (Mannheim and Bremen), Eisenhart (Heilbronn), Saint George, and the archangel Michael (Hamburg and Breslau), of historical heroes (Henry the Lion, Brunswick; Charlemagne, Itzehoe) and mythical ones (Siegfried,

1 M. Diers, Propaganda mit ephemeren Denkmäler im Ersten Weltkrieg, in: idem, Schlagbilder. Zur politischen Ikonographie der Gegenwart, Frankfurt/Main 1996, pp. 78-100 , here: p. 78. Even the examples from Ancient Rome were brought up, such as hammering the nails for the goddess Northia to "close the year", or the subsequent form of amulets. G. Schneider, Über Hannoversche Nagelfiguren im Ersten Weltkrieg, „Hannoversche Geschichtsblätter" 1996, vol. 50, p. 213. The reference to the preceding military traditions is also included in the entry in „Meyers Großes Konversations - Lexikon”, Wien 1906, vol. 14, p. 376, describing Nageleinschlagen as symbolischer Brauch, e.g. feierliche Nagelung Armeefahnen. Cf. G. Schneider, Zur Mobilisierung der „Heimatfront“: Das Nageln sogenannter Kriegswahrzeichen im Ersten Weltkrieg, „Zeitschrift für Volkskunde” 1999, vol. 95, p. 33.

2 G. Schneider, In eiserner Zeit - Kriegswahrzeichen im Ersten Weltkrieg, Schwalbach, Ts. 2013, p. 45; the author describes those groups as Stammtischgesellschaften.

3 Ibidem, p. 44.

4 Ibidem, p. 52. 
Wiesbaden), and medieval knights, but also animals: an eagle (Frankfurt am Main), lion (Düsseldorf), horse, raven, griffin (Baden-Baden), and even aeroplanes (Gotha) and submarines (Hörnum on the island of Sylt, Kiel). The cities' coats of arms, symbols of the first Reich (Holy Roman Empire), such as an eagle (Reichsadler), signs of the Red Cross, trees, and many variations of those motifs were also utilised. Among the ones used most often was the Iron Cross. Many monuments of that kind were dedicated to the war hero of that time, the victor from Tannenberg, Field Marshal Paul von Hindenburg, commonly called the liberator of the East (Ger. Befreier des Ostens). Thanks to the battle at Tannenberg, which was a turning point for the Eastern Prussia segment of the eastern front, the Russian armies were driven out of that German province. The Field Marshal was also immortalised in Berlin as „Eiserne Hindenburg” in a gargantuan iron-nail figure, 12 metres tall and with 26 tons of weight, designed by the Berlin painter Georg Marschall; its "unveiling" took place on 4 September 1915 in Königsplatz in the vista of the Victory Column. ${ }^{5}$ The celebration of the first "nailing" was attended by representatives of the highest state authorities, led by the Chancellor of the German Empire Theobald von Bethmann Hollweg. That no monument referred directly to the Emperor Wilhelm II seems particularly consequential.

Those memorials, designed to be temporary as they were made from wood, were supposed to serve not only to gather an ad hoc support for the soldiers, their families, and the loved ones of the victims in need through the hammering nails ceremony. The involvement of the civilian population of cities, women and children, members of associations, school students, was expected to mobilise and integrate the society in the homeland front (Ger. Heimatfront). It was to be an event for the whole community, a display of patriotism, and to intensify the enthusiasm for the war, not always so common as it would appear during its first weeks. ${ }^{6}$ That endeavour spoke to a mystical need of being in the place of worship - as "the iron

5 M. Rapsilber, Der Eiserne Hindenburg von Berlin: Ein Gedenkblatt, Berlin 1918.

6 G. Schneider, In eiserner Zeit, p. 99. 
monuments" became kind of a fetish - but also of immortalizing it through the symbolical hammering of the nail. ${ }^{7}$

The monuments were also a powerful instrument of the state's war propaganda, affecting the newly arising construct of the public awareness, essential in the time of conflict. Many of the monuments were initiated by the members of the German Red Cross, subordinate to the Ministry of War. ${ }^{8}$ They were not war monuments (Ger. Kriegerdenkmal) per se, but they can be included in this category. It is vital to note that the purpose of this practice was, most of all, to enable the collection of funds for all the categories of the war victims. The applicable regulations concerning the support for the families of the military casualties dated back to 17 April 1907 and did not guarantee appropriate financial aid given the scale of needs. Four years after the conclusion of the war there were over half a million widows of the soldiers in Germany, 1.2 million half-orphans, 1.5 million irreversibly disadvantaged disabled soldiers. ${ }^{10}$ Nevertheless, even in the initial period of the war when the number of victims had not yet reached these levels, many of the German families were left destitute, one of the reasons for which was a high unemployment rate among women.

On 1 August 1915 „Nagelung von Wahrzeichen” was recognised as part of the German National Endowment (Ger. Nationalgabe) under the protection of Marshal Hindenburg. ${ }^{11}$ The funds from the sale were placed in three-fourths to nation-wide German National Foundation (Nationalstiftung) and the remaining quarter was distributed locally, i.a. to the charities, which was supposed to potentiate the generosity. ${ }^{12}$

As the idea of those "iron-nail war landmarks" spread, attempts were made to give them a more unified form. It would meet both the objectives of the patriotic propaganda and the wartime needs to save resources and materials, both financial means and e.g. metals indispensable to the war

7 H. Rausch, Kultfigur und Nation. Öffentliche Denkmäler in Paris, Berlin und London 1848-1914, München 2006, p. 660.

8 M. Diers, Schlagbilder. Zur politischen, p. 90.

9 G. Schneider, In eiserner Zeit, p. 13.

10 Ibidem, p. 12.

11 Ibidem, p. 48.

12 M. Diers, Schlagbilder. Zur politischen, p. 39. 
economy. Hence the emergence of publications with suggestions of design for this type of monuments in $1915 .{ }^{13}$ Patriotic expression often crossed the thin line between art and kitsch; the aesthetics of the "iron monuments", or more precisely, the lack of it, as well as their triviality and literalism were criticised as early as the unveiling of Hindenburg's colossus in Berlin. The remonstrations against this kind of installations in the public space, addressed to the authorities of Berlin, emerged shortly after the celebrations of "driving the first nail in" at the beginning of September 1915. Even the very method of executing the public generosity by hammering the nails into statues representing people, including the living ones (Hindenburg), seemed barbaric, primal, and uncivilised to the critics. ${ }^{14}$ The artistic circles spoke out against the mediocre artistic quality of most of these memorials. ${ }^{15}$

The monuments were placed in the most representative areas, such as open city squares, not only for the prestige, but also because the "nailing" (Ger. Nagelung) ceremonies needed enough space to accommodate a large number of participants and observers, as well as honorary guests. The sense of belonging to the community, which was supposed to be enhanced by participating in the ceremonies, was sometimes authenticated with the special certificate in the form of so-called Nagelkarte. ${ }^{16}$ It is remarkable that the monuments were quite often "unveiled" by women, e.g. in the case of the princess Augusta Wilhelmina Hohenzollern unveiling the statue of Hindenburg in Berlin. ${ }^{17}$ While the women did not take part in the fight itself, they had indirectly grown in importance on the home front through this practice. The organisation of those events was based on the patriotic pilgrimages to the older memorials, e.g. the "war monuments" typical of the Wilhelmine era, mostly related to the Franco-Prussian War 1870-1871,

13 Kriegs-Wahrzeichen zum Benagelung. 69 Entwürfe aus einem Preiswettbewerb des deutschen Werkbundes, München 1915.

14 H. Rausch, Kultfigur und Nation, p. 662.

15 H. Sachs, Vom Hurrakitsch, von Nagelungsstandbilder, Nagelungsplakaten und anderen Schönheiten, "Das Plakat" 1917, vol. 8 (1).

16 S. Goebel, "Kohle und Schwert". Zur Konstruktion der Heimatfront in Kriegswahrzeichen des Ruhrgebietes im Ersten Weltkrieg, "Westfälische Forschungen” 2001, vol. 51, p. 259.

17 H. Rausch, Kultfigur und Nation, p. 661; “Die Presse” 1915, vol. 33, issue 208 (9). 
but also the celebrations under the Bismarck columns, hundreds of which were raised after the death of the former Chancellor in $1898 .{ }^{18}$ A whole organisational system emerged around the monuments to ensure a solemn celebration of the hammering of symbolic nails. They were available at various prices, e.g. nails made from iron could be bought for 50 pfennigs, those coloured silver for 2 to 5 marks, while the "golden" ones could cost 100 marks and more. ${ }^{19}$ The names of donors were documented in honorary books (Ger. Nagelbuch, Eisernes Buch).

Euphoria which surrounded the monuments reached its peak in the second half of 1915 and at the beginning of 1916, when it encompassed even the smaller German cities; but the wave of Kriegsnagelungen passed as fast as it had spread. With the war extending, many victims on the front lines (winter 1915/1916 brought 2.5 million soldiers' deaths), growing burdens for the civilian population, destitution, change of public sentiments and their radicalisation, generosity in that form became onerous. Although most likely the last war nailing (Ger. Kriegsnagelung) was held close to the end of the war in July 1918 in Marbach in Württemberg, since the end of 1916 and the beginning of 1917 such initiatives generally had been dying down. ${ }^{20} \mathrm{~A}$ great number of the war victims necessitated the emergence of the new forms of gathering aid funds, such as so-called Gedächtnisnägel (remembrance nails) dedicated to the commemoration of the deceased. ${ }^{21}$ Eventually, in December 1916 Prussian Ministry of Internal Affairs announced the formal discontinuance of the endeavour. ${ }^{22}$ Even though it encompassed about 750 German cities, there were some centres which did not

18 S. Goebel, The Great War and Medieval Memory. War, Remembrance and Medievalism in Britain and Germany, 1914-1940, Cambridge 2007, p. 54.

19 M. Diers, Schlagbilder. Zur politischen, p. 88. Nota bene "Hindenburg's nails" became the object of profiteering. As "Gazeta Toruńska" reported, not without some malice, in Berlin many girls and women were involved in illegal sales of those nails at inflated prices of 5 and 10 marks, whereas normally only the paper coupon was bought and the nail itself was handed over by the soldiers at the monument. "Gazeta Toruńska”, vol. 51, issue 234, 12 IX 1915, p. 4.

20 G. Schneider, In eiserner Zeit, p. 56.

21 S. Goebel, "Kohle und Schwert", p. 263.

22 Ibidem, p. 264. 
undertake those initiatives; among those, the larger ones include Karlsruhe, Fulda, Göttingen, Konstanz, Hildesheim, Tübingen, and Weimar. ${ }^{23}$

Some of the iron-nail statues in the war time were completely covered with nails, fulfilling their task; e.g. the Wehrmann in Eisen in Vienna gathered about 500 thousands of nails. The gargantuan iron-nail figure of Hindenburg in Berlin, however, was not fully covered (around 800 thousands of nails were hammered in); the longer the war, the more generosity declined. Most likely, the highest sum was accumulated in Cologne (approx. 1.5 million marks), while approx. 270 thousands were gathered in Hamburg. According to the assessments, all the nailing ceremonies in the German Reich allowed to gather 10-12 million marks. ${ }^{24}$

In some cases, it is difficult to ascertain the further fate of those ephemeral monuments and to determine whether they were preserved in their original locations to the end of war. Having served their purpose, they generally disappeared from the public places, having been passed to schools or deposited in the military memorial sites and museums. After 1918, the monarchy of the Hohenzollerns ceased to exist, and the social conditions as well as the collective memory changed. Thus, a large number of the monuments ceased to exist; their preservation was also not favoured by the assumed impermanence of the material, wood, from which most of them were made. One example is the fate of the Berlin statue of Hindenburg, which was banished from the city square by the directorate of the Tiergarten park after the war had finished. Then it was split into 21 parts and disappeared in a shed, only to be later used as firewood. ${ }^{25}$ In 1938 its head was found; it was intended to be put in Märkisches Museum, but eventually found its way to the aeroplanes collection on Lehrter Bahnhof, where it did not outlast World War II. As evidenced by the assembled documentation, ${ }^{26}$ about a thousand of them were risen in the German Reich, but only an infinitesimal number of them have been preserved to this

23 G. Schneider, In eiserner Zeit, p. 60.

24 Ibidem, p. 89.

25 M. Diers, Schlagbilder. Zur politischen, p. 96.

26 G. Schneider, In eiserner Zeit, catalogue pp. 99-507; it is also possible to use its incomplete version available on the Internet. A short report can be found there: $\mathrm{dr}$ D. Munzel-Everling, Kriegsnagelungen. Wehrmann in Eisen. Nagel-Roland. Eisernes Kreuz, 
day. The monuments were also built in cities of Austria-Hungary, Turkey, and also outside Europe, e.g. Argentina and USA (San Francisco, September 1915). ${ }^{27}$ The Kriegsnagelungen were not the only form of the social fund raising for supporting the victims of war; at the same time, other aid campaigns were being run in the Reich, e.g. collecting clothing or gold, as well as local ventures, such as Ostpreußenhilfe held for the eastern province of the country which had been destroyed by the Russians.

In the then West Prussia, which belonged to the German Empire and roughly covered the geographical area of Pomerelia, interest for nailing idea also appeared relatively early. One of the first attempts to develop technical issues was published in August 1915 in "Zentralblatt der Bauverwaltung" by PhD. Eng. Hermann Phleps from the local Technische Hochschule in Gdańsk (Ger. Danzig). ${ }^{28}$ The paper presented a few most practical and exemplary designs.

They were, most of all, various kinds of wooden planes, on which one could create decorative patterns from the hammered nails, such as the images of the Iron Cross, an eagle, oak leaves wreath, sword, torch, date or royal initials. The tablets hanging in the interiors or outside the buildings like churches, town halls or city gates, but also decorating old gates or doors could be used for that purpose. Another form of commemoration could be the wooden beams above the entrances.

However, the form preferred by $\mathrm{H}$. Phleps, with regard to its aesthetic and purely technical virtues, were wooden columns. The author particularly emphasised that they referred to the old Teutonic tradition. Divided into smaller planes by metal rings, most often crowned with the Iron Cross, they were supposed to constitute the perfect expression of patriotic feelings in a practical and frugal way. After the act of decorating their surface with the sacrificial nails concluded, they were preserved, according to the author's instructions, with linen varnish, and were supposed to last in the

Wiesbaden 2008, http://www.munzel-everling.de/download/munzel_nagelfigu-ren.pdf [access: 18. 02. 2016].

27 G. Schneider, Über Hannoversche Nagelfiguren, p. 215.

28 H. Phleps, Über Kriegsnagelungen, "Zentralblatt der Bauverwaltung" 1915, vol. 35 (69), (28 VIII 1915), pp. 453-455. 
public space as a clear symbol of the commitment to the state, its ruler and the army leading to victory. Additionally, they could be equipped with suitable handles and transformed into a spot to lay wreaths. As they only required a small number of resources and cheap materials (pine wood, small iron elements, preservatives), they became widely available even for the smallest of towns.

A column exhibited in Gdańsk served as a model example of such a solution - the metal rings reinforcing its wooden core were dedicated to members of the ruling family and commanders of the army distinguished for their victories in the East. The upper part held the names of the emperor Wilhelm II, the crown prince Wilhelm and the younger brother of the emperor, prince Heinrich; below, Marshal Paul von Hindenburg, Marshal August von Mackensen, hero of the fights in Eastern Prussia, minister of war Erich von Falkenhayn, in the third row the admirals Alfred von Tirpitz and Maximilian von Spee and the U-boot commander Otton Weddingen, who died in March 1915. A special plaque in a form of coat of arms was dedicated to children of the crown prince and his wife Cecilia, the only daughter, princess Victoria Louise Hohenzollern, and five sons. On its edges, there was space was left for the city's honour guests. The spaces between the clamping rings were devoted to the nails hammered in by the donators, arranged in the shape of the oak leaves. The column was exhibited on the ruins of the bastion of Saint Elizabeth, close to the Central Station. Its very solemn "unveiling" took place on 1 August 1915, on the anniversary of the outbreak of the war, on a day which was established as the so called sacrificial day (Ger. Opfertag). The wife of the heir apparent, present in Gdańsk, took a hammer from the hands of the column's designer and drove the first nail in. The high level army and navy commanders along with the representatives of civil authorities - from the Gdańsk region and the city of Gdańsk followed in her footsteps. ${ }^{29}$ The ceremony was attended by the whole garrison stationed in Gdańsk. It was preceded by a church service in St. Mary's Church in which princess Cecilia participated, and

29 Description of the celebrations: "Die Presse” 1915, vol. 33 (203) (31 VIII), Königsberger Hartungsche Zeitung 1915 (356) (2 VIII 1915), Abendausgabe; “Die Presse” 1915, vol. 33 (179) (3 VIII). 


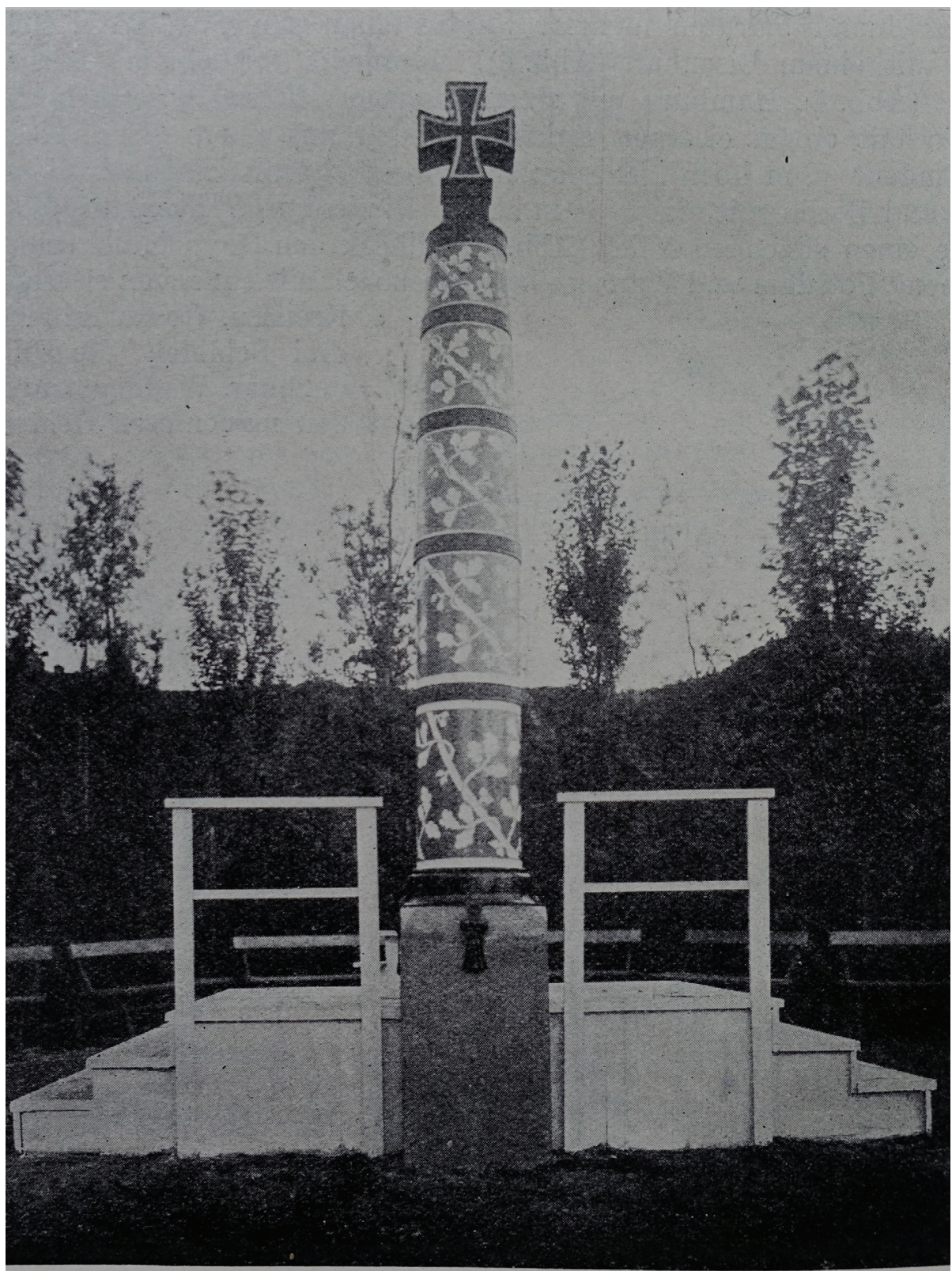

Danziger Kriegssäule (a war column) in Gdańsk 
in the afternoon thousands of Gdańsk's citizens celebrated this occasion out in the open in Wrzeszcz (Ger. Langfuhr).

A similar model of memorial was chosen in Toruń (Ger. Thorn). In this case, in the Torun Kriegssäule, it was not the whole multi sided wooden column that was decorated with iron votive offerings in the form of nails, but only the Iron Cross made from the same material and placed on top, inscribed with the date $1914 .{ }^{30}$ This monument commemorated the August victory over the Russian army at Tannenberg, pivotal for the eastern provinces of the Reich, including West Prussia. It was exhibited on the western side of the Old Town Square, by the existing monument dedicated to Wilhelm I, the King of Prussia and the first Emperor of the Second Reich. The ceremony of its unveiling on Sunday, 29 August 1915, completed the celebrations of the first anniversary of this battle. ${ }^{31}$ The preceding evening a concert was organised in the Evangelist Church on the Old Town Square, and on the Sunday morning services were held in all the city churches and in the synagogue, preceded by a signal from the town hall tower. The ceremony itself began at noon. In the afternoon, crowds celebrated in the Brickyard Park in Bydgoskie Przedmieście. Even before the celebrations, about a thousand of nails were sold along with the cards confirming the purchase (the so called Nagelkarten); such a large number made it impossible to drive all the nails in on that day. Bows, prints, postcards, ribbons were also sold, which further increased the income; according to assessments, it reached fifteen thousand marks on that day. The initiator of this endeavour was Thorner Hauptausschuß für Kriegswohlfahrtspflege established in September 1914..$^{32}$ The deputation which was charged with managing the aid campaign included representatives of the Magistrate and women's organisations, as well as other town associations. At the end of 1915, the monument of the "Iron Cross" was relocated to the Old Town Square. In the days preceding the so called charity day (Ger. Opfertag)

30 For details of the Toruń monument history see: M. Niedzielska, Nieznane wojenne pomniki Torunia z 1915 roku, "Rocznik Toruński” 2015, vol. 42, pp. 57-74.

31 “Königsberger Hartungsche Zeitung”, issue 404, 30 VIII 1915, Abendausgabe.

32 Archiwum Państwowe w Toruniu (following APT), Stowarzyszenie Kobiet w Toruniu, sign. 14, p. 25. 


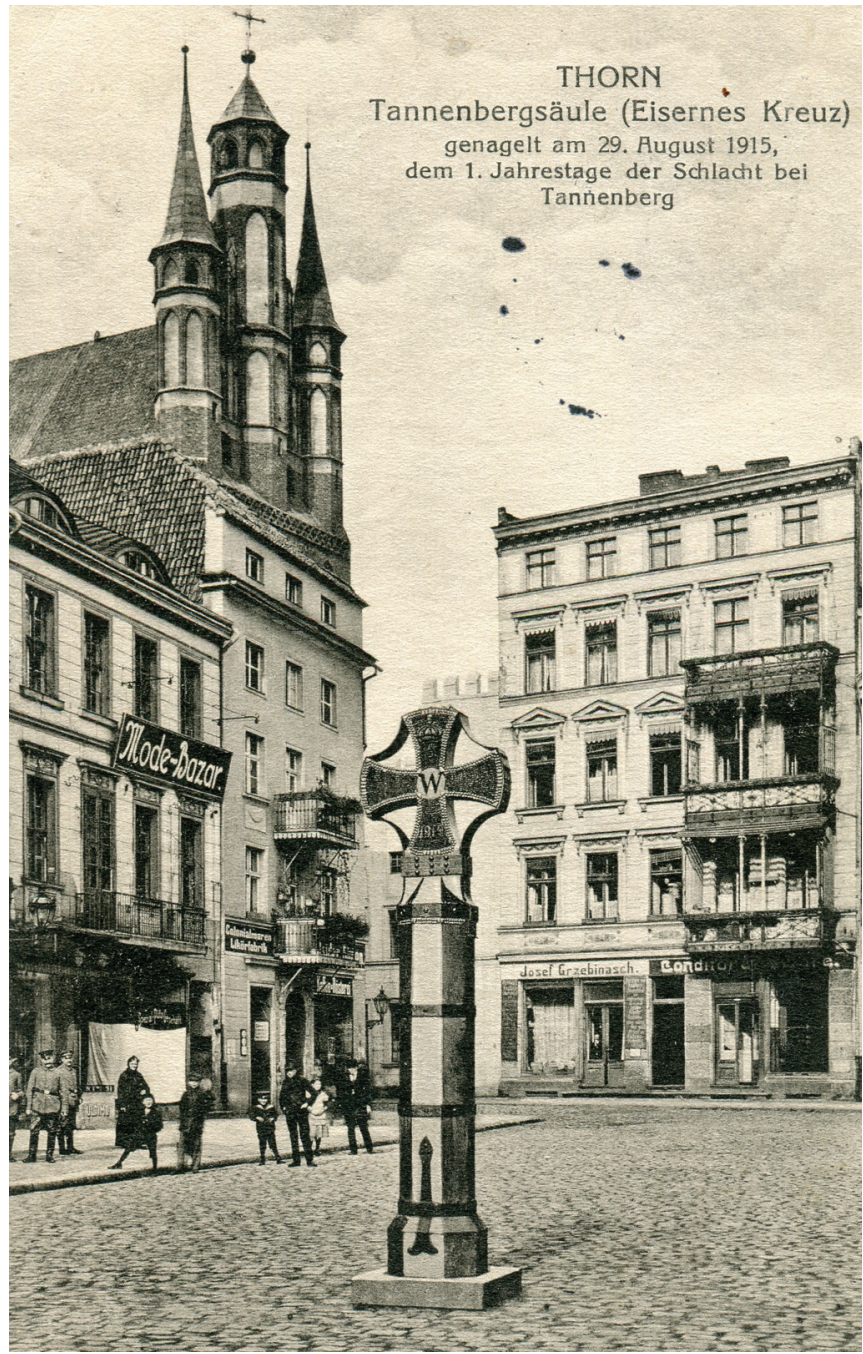

Iron Cross in Toruń

which fell in 1916 on 3 September, another activity was held, namely writing in a golden book (Das Goldene Buch der Thorner Kriegswohlfahrtspflege). Its pages were laid out in many places, e.g. under the statue of the Emperor Wilhelm I and Copernicus in the Old Town Square, in shops, in the office of the newspaper "Die Presse" on the St. Catherine's street. The 
donations ranged from one up to a thousand marks. The celebrations were accompanied by numerous concerts in the Torun restaurants and in the Brickyard Park. ${ }^{33}$ It can be also assumed that the column was completely covered as soon as in 1915 and it could not be used in the subsequent year. The recollection of this not widely known iron-nail landmark from 1915, even though it was temporary in principle, is worth reviving in Torun's memory, especially that its images have been preserved. A theme of the column of victory at the Tannenberg was also chosen by the initiators from the association of railway companies of the Bydgoszcz region (Verband der Eisenbahnvereine des Direktionsbezirk Bromberg) in neighbouring Bydgoszcz, belonging to the Poznań province (Ger. Provinz Posen). The monument was wrought by craftsmen from the Bydgoszcz railway plants. The wooden obelisk, two and a half metre tall was decorated on its apex with the German railway symbol in a form of a winged wheel worn on the uniforms (so called Flügelrad), and in the lower part with an image of the Iron Cross. On iron clamping rings, there were names of towns: Tannenberg, Olsztynek (Ger. Hohenstein), Dąbrówno (Ger. Gilgenburg), and Kętrzyn (Ger. Rastenburg), as well as the names of leaders: Hindenburg, Mackensen, v. Scholz and v. François. The first nails were driven in during the ceremony on 7 September, in the name of the absent marshals, by the district counsellor and a veteran from the Franco-Prussian War 1870-1871, along with the wife of the railway president. In a short time, around 3500 marks were raised. ${ }^{34}$ In nearby Fordon, a similar monument was displayed in the town square, and the ceremony of nails hammering was connected with the celebrations of the anniversary of the Hohenzollern dynasty at 24 October $1915 .{ }^{35}$ Designed by the mayor, a wooden Iron Cross was wrought by the Bydgoszcz company belonging to A. Dittmann and the nails were

33 "Die Presse" 1916, vol. 34 (207): "Zu erwarten ist, daß auch das Goldene Buch, dessen Blätter an verschiedenen Stellen, auch in der Geschäftsstelle unserer Zeitung, zur Zeichnung ausliegen, einer ebenso reichen Ertrag bringen wird, wie die Nagelung des Eisernen Kreuzes, an dessen Stelle in diesem Jahre die Einzeichnung in das Goldene Buch getretenist"; cf. issue 206, issue 208, issue 213.

34 The description of ceremony: "Königsberger Hartungsche Zeitung" 1915, issue 421, Morgenausgabe.

35 “Die Presse” 1915, vol. 33 (253). 
made by the local jeweller. A representative of the Jewish community took part in the ceremony alongside representatives of the district and the town authorities.

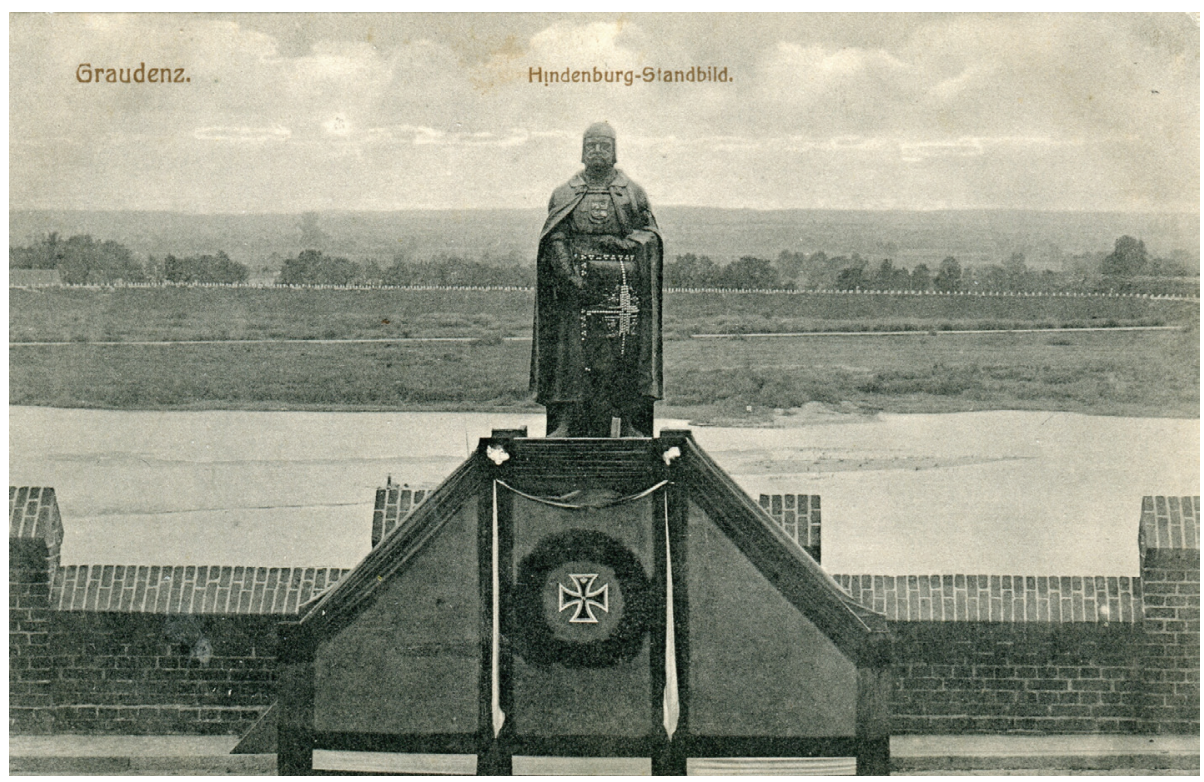

Statue of marshal Paul von Hindenburg in Grudziądz

In Grudziądz (Ger. Graudenz), a statue of marshal Paul von Hindenburg dressed up as a knight of the Teutonic Order was installed, as a symbol of the German colonisation in the East; the author was a sculptor from Kassel, Schmidt.

During the ceremony of nailing the monument on Sunday 29 August 1915, a miniature shields of Teutonic Knights sculpted in wood were sold by the soldiers injured at Tannenberg. This day, many services were held in churches, accompanied by sport events and outdoor concerts. The income was estimated at 25 thousand marks. ${ }^{36}$ Placed on the walls near the town hall, the monument became a central point of the panorama of the Vistula embankments.

36 Ibidem, issue 204. 


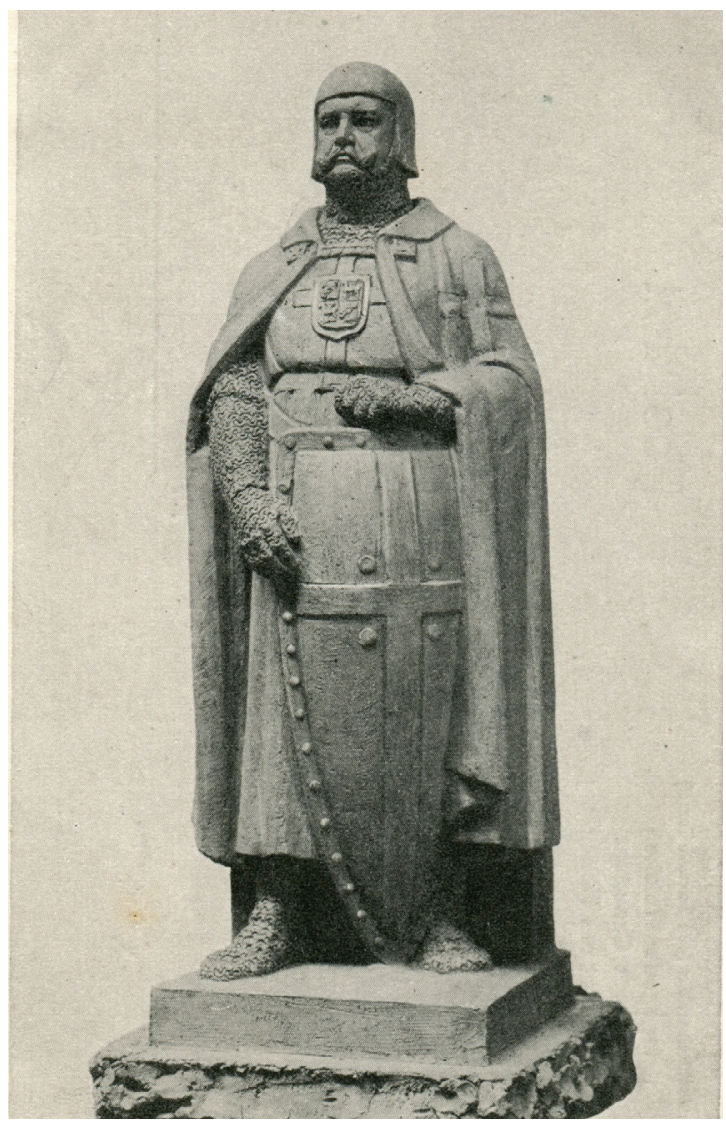

Statue of Paul von Hindenburg in Grudziądz

The Hindenburg theme appeared also in Węgorzewo (Ger. Angenburg), Tylża (Ger. Tilsit) and Wystruć (Ger. Insterburg) in Eastern Prussia, while in Gąbin (Ger. Gumbinnen), the district authorities seat, on Marshal's birthday, 2 October 1915, a nailing of the plaque dedicated to him took place and the income from the fundraising was intended for the injured soldiers in the local hospital. ${ }^{37}$

Patriotic atmosphere did not omit the capital Królewiec (Ger. Königsberg). From August 1915, the most appropriate form of memorial was

37 “Königsberger Hartungsche Zeitung” 1915 (441), Morgenausgabe. 
discussed; according to the press reports, at the beginning, the preferred motif for the statue was Hans von Sagan, probably a fictional character, supposedly a shoemaker's student who participated in the wars of the Teutonic Order in the fourteenth century and became a symbol of the town by the Pregoła river (Ger. Pregel).

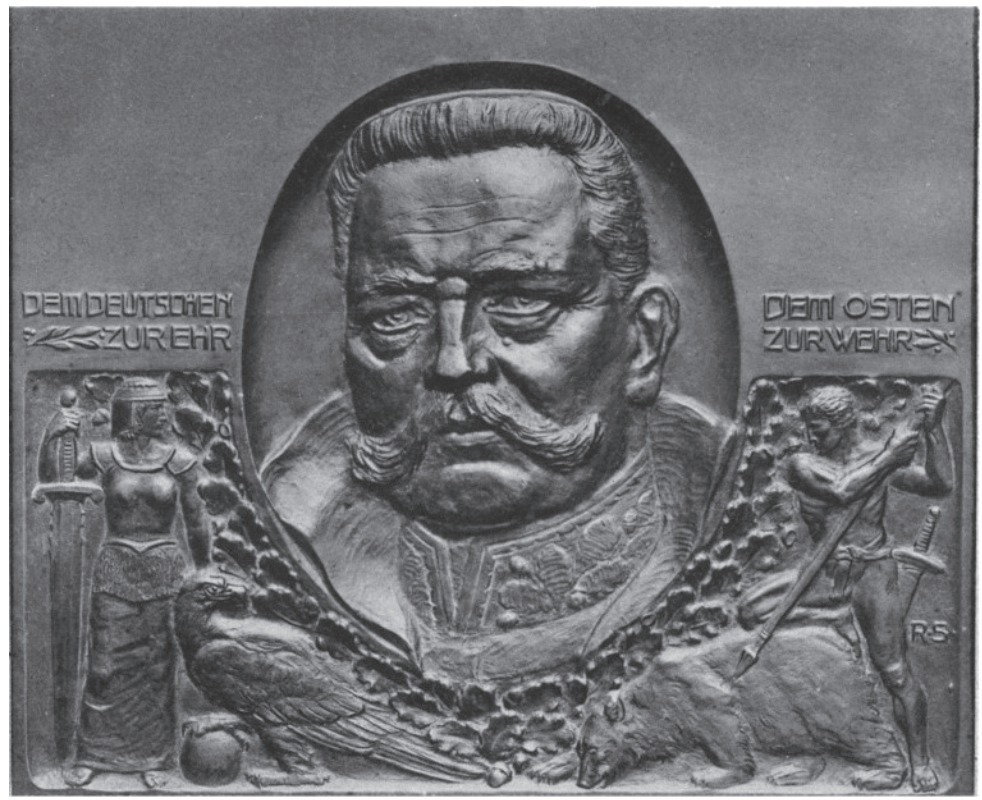

Plaque with motif of Paul von Hindenburg, Tylża

Eventually, another model prevailed, a statue of Roland leaning on his sword, a knight in armour (Ger. Eiserne Wehrmann). It was planned to be surrounded by a 12 metres high temple, supported by columns. Both the permanent form of the landmark and the location on the main square of the city (Ger. Paradeplatz) made the royal endeavour an exception among the similar ventures. The works began on 20 September and the unveiling ceremony was held on 21 October 1915 which, as was emphasised, was both the empress's birthday and the $500^{\text {th }}$ anniversary of the first monarch from the Hohenzollern dynasty ascending the Brandenburg throne, granting it a very high profile. The lord mayor of Królewiec drove in the first nail in the name of Marshal Hindenburg, accompanied by a choir of several 
hundred singers, the garrison orchestra, soldiers from its ranks and the generals. The pressure for buying nails was so high that it caused some chaos on the day of celebrations. They could also be bought later at stalls in front of the statue and several other places in the city, including the office of the women's association Vaterländischer Frauenverein, which initiated the whole endeavour. ${ }^{38}$ The youth sold the so called Nagelkarten worth one and two marks. Completely filled with nails, the statue of a knight in armour was later kept in the town hall in one of the parts of Królewiec - Knipawa (Ger. Kneiphof), and afterwards, in a museum. It did not survive the air raid by the Allies in August 1944.

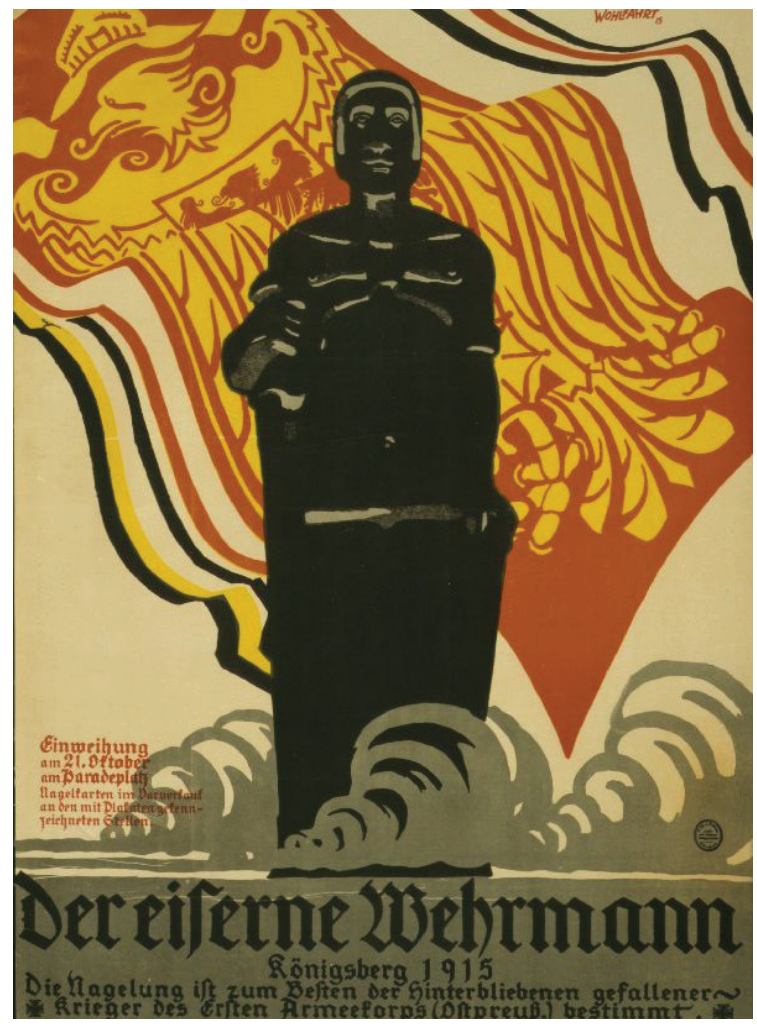

Eiserner Wehrmann, Królewiec

38 “Königsberger Hartungsche Zeitung” 1915 (356), Abendausgabe; (441), Morgenausgabe; (495), Morgenausgabe (description of the unveiling ceremony). 
The Eiserne Wehrmann from Królewiec became one of the most recognisable symbols of generosity of the Eastern Prussians during the First World War; a poster with his image is one of the blatant examples of German patriotic propaganda of that time. The fate of those monuments clearly indicates that not only the wood is perishable; the patriotic upheaval regarding the matter eventually proved to be elusive, just as the German Reich and the Hohenzollern dynasty.

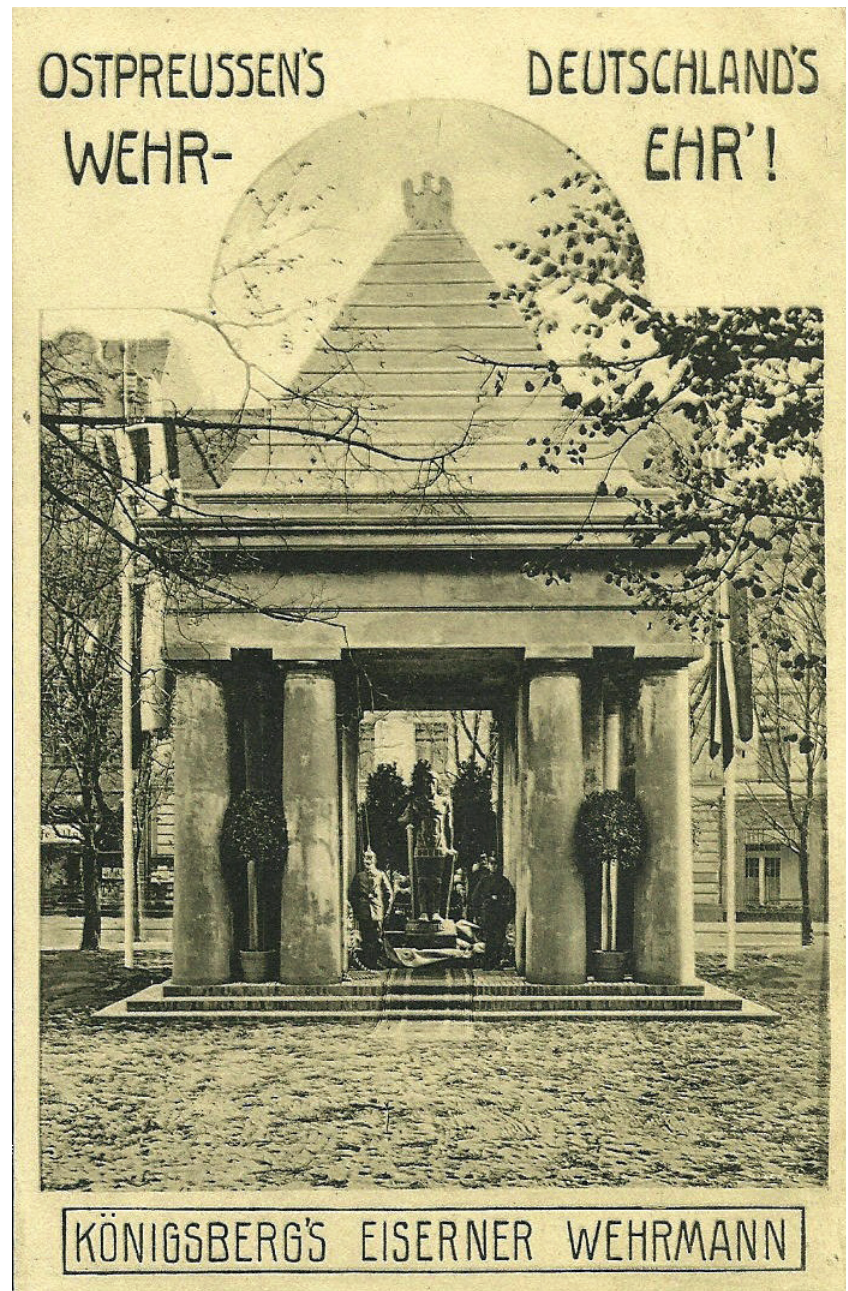

Eiserner Wehrmann, Królewiec 


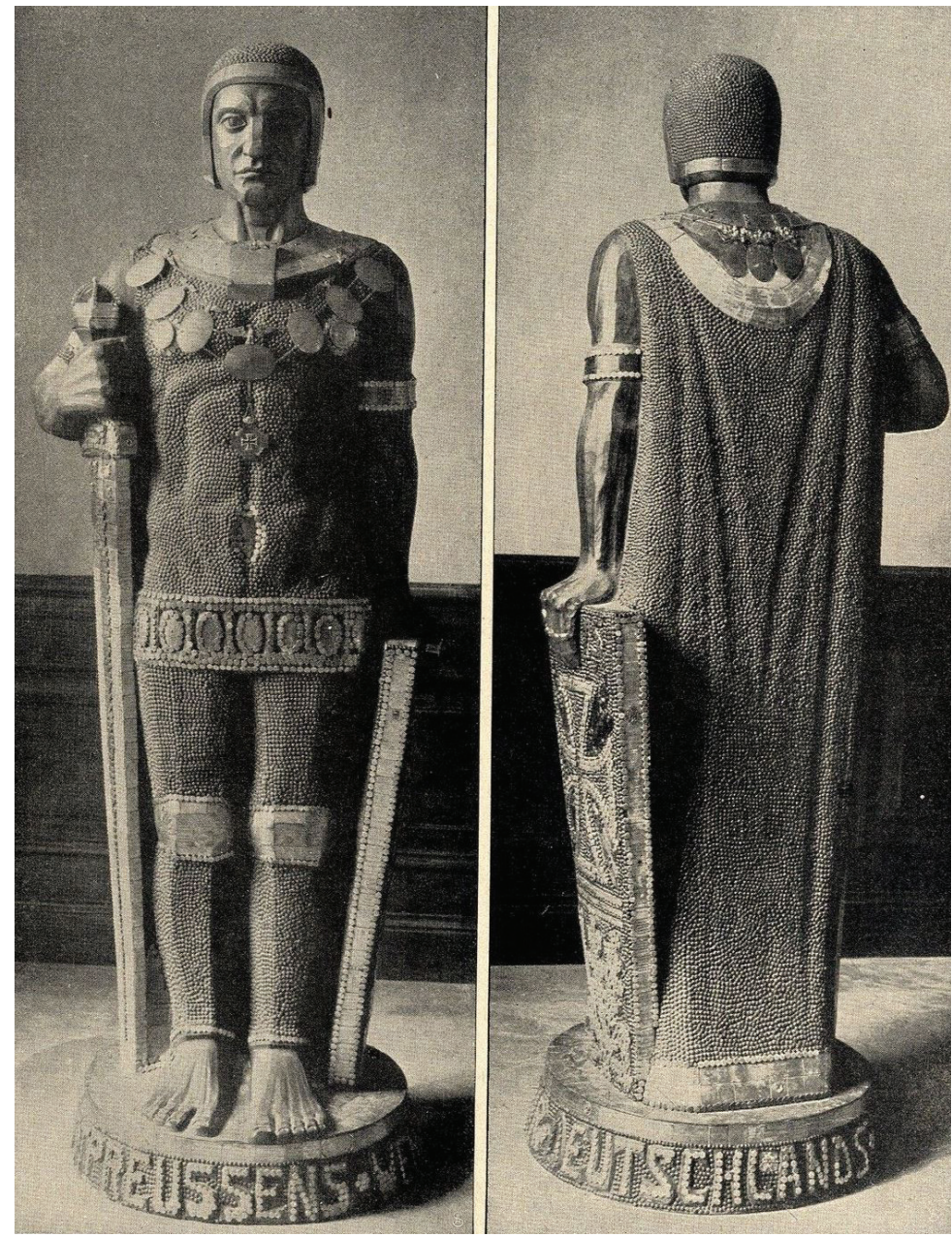

Eiserne Wehrmann - statue in Królewiec

The "iron-nail war landmarks" from the Great War period had not become part of the German memorial culture in the twentieth century not only because the conflict from 1914-1918 was overshadowed by the next war with all its grave consequences. Even at the moment of their creation, their main function was to form attitudes about the present, not the past. Ephemeral in form, they could only fulfil the need of the social consolidation and national identity in view of the current, war goals. Their 
disappearance planned in statu nascendi is, however, quite an exceptional case, as the significant elements of the present are typically preserved for the cultivation of the past in the future. The "iron monuments" were, most of all, means to unify the German nation in the face of war, and the territorial identity of the smaller communities could only demonstrate in the choice of symbols used. The number of those monuments in both of the eastern, "Prussian" in a limited sense, provinces of the Reich is so small that it is difficult to find any conceptual features that would distinguish those endeavours from the ones emerging in the other parts of the country. One of those symbols could be Hindenburg - because of his place of birth as well as the significance of the victory at Tannenberg for Eastern and Western Prussia. Such characteristics could also be expressed by the theme of the Iron Cross, referring to the role of Eastern Prussia during the Napoleonic wars. The purpose of those monuments was to focus society as a whole around the symbols related exclusively to the German or even Teutonic historical tradition. The German war act became rooted in this heritage as well, regardless of the fact that the soldiers representing numerous national and ethnic minorities which resided there, including Poles, were fighting in the armies of the Central Powers (the German Empire and the Habsburg Monarchy). As a result, the Polish community did not identify with those ventures. It is telling that the Polish press kept silent about those events; for example, "Gazeta Toruńska" failed to mention the landmark of the Iron Cross erected in 1915 in Torun in the Old Town Square. It also explains the complete absence of this topic in the works of Polish authors. ${ }^{39}$ Finally, another reason was an acute lack of other sources than German newspapers. ${ }^{40}$ This topic then, beyond doubt, requires further exploration and research.

39 About the issues of memory and identity cf. R. Traba, "Wschodniopruskość. Tożsamość regionalna $i$ narodowa $w$ kulturze politycznej Niemiec, Poznań-Warszawa 2005. It must be noted that in Germany those problems were absent in historiography for many years, and it was "brought back" only at the end of 1990s and the beginning of 2000s.

40 For example, in the National Archives in Torun scant files were preserved, but they do not contain information about the monument itself (Akta Miasta Torunia C, sign. 8947 - anniversary of the battle at Tannenberg, 9356 Tannenbergfeier 1917-1918). 
